Gül, E. ve Koçak, D. (2021). “işle İlgili Kaygı Ölçeğinin Türkçe Uyarlaması ve Dönüştürücü Liderlik ile iş̧ Performansı Arasındaki ilişki: İş Özerkliğinin Aracı ve İşle illgili Kaygının Düzenleyici Rolü”, Eskişehir Osmangazi Üniversitesi iiBF Dergisi, 16(3), 821 - 841.

Doi: $10.17153 / o g u i i b f .973763$

Başvuru: 22.07.2021 Kabul: 02.09.2021

Araştırma Makalesi/Research Article

\title{
İşle İlgili Kaygı Ölçeğinin Türkçe Uyarlaması ve Dönüştürücü Liderlik ile İş Performansı Arasındaki ílişki: İş Özerkliğinin Aracı ve İşle îlgili Kaygının Düzenleyici Rolü
}

\author{
Emre Gül ${ }^{1}(\mathrm{ic})$ \\ Daimi Koçak ${ }^{2}$
}

\begin{tabular}{|c|c|}
\hline $\begin{array}{l}\text { İşle ilgili Kaygı Ölçeğinin Türkçe Uyarlaması ve } \\
\text { Dönüştürücü Liderlik ile İş Performansı Arasındaki iliş̧ki: } \\
\text { İş Özerkliğinin Aracı ve İşle İlgili Kaygının Düzenleyici } \\
\text { Rolü }\end{array}$ & $\begin{array}{l}\text { Turkish Adaptation of the Job-Related Anxiety Scale } \\
\text { and the Relationship between Transformational } \\
\text { Leadership on Job Performance: The Mediating Role of } \\
\text { Job Autonomy and Moderating Role of Job-Related } \\
\text { Anxiety }\end{array}$ \\
\hline Öz & Abstract \\
\hline $\begin{array}{l}\text { Bu araştırmanın amacı Parker ve DeCotiis (1983) } \\
\text { tarafından geliştirilmiş olan işle ilgili kaygı ölçeğinin } \\
\text { Türkçe uyarlamasını yapmaktır. Ayrıca mevcut çalışmada } \\
\text { dönüştürücü liderliğin iş performansı üzerindeki } \\
\text { etkisinde iş özerkliğinin aracı ve işle ilgili kaygının } \\
\text { düzenleyici rolü incelenmiştir. Ölçeğin uyarlamasını } \\
\text { yapmak için hemşirelerden oluşan birinci örneklemden } \\
\text { (n=159), araştırma hipotezlerinin testinde ise Türkiye' } \\
\text { de hizmet sektöründe faaliyet gösteren özel bir şirketin } \\
\text { çalışanlarından oluşan ikinci örneklemden (n = 237) } \\
\text { yararlanılmıştır. Yapılan analizlerde işle ilgili kaygı } \\
\text { ölçeğinin orijinal tek faktörlü yapısının desteklendiği } \\
\text { tespit edilmiştir. Bununla birlikte, dönüştürücü liderlik ile } \\
\text { iş performansı arasındaki ilişkide iş özerkliğinin aracı ve } \\
\text { işle ilgili kaygının düzenleyici rolünün olduğu } \\
\text { belirlenmiştir. }\end{array}$ & $\begin{array}{l}\text { The purpose of this study is to adapt the job-related } \\
\text { anxiety scale developed by Parker and DeCotiis (1983) } \\
\text { into Turkish. Besides, in the current study the mediating } \\
\text { role of job autonomy and the moderator role of job- } \\
\text { related anxiety in the effect of transformational } \\
\text { leadership on job performance were examined. In order } \\
\text { to adapt the scale, the first sample }(n=159 \text { ) consisting of } \\
\text { nurses and, in testing the research hypotheses the } \\
\text { second sample ( } n=237 \text { ) consisting of employees of a } \\
\text { private company operating in the service sector in } \\
\text { Turkey was used. In the analysis, it was determined that } \\
\text { the original single-factor structure of the job-related } \\
\text { anxiety scale was supported. However, it was } \\
\text { determined that job autonomy has a mediating effect } \\
\text { and job-related anxiety has a moderating effect on the } \\
\text { relationship between transformational leadership and } \\
\text { job performance. }\end{array}$ \\
\hline $\begin{array}{l}\text { Anahtar Kelimeler: İşle İlgili Kaygı, Ölçek Uyarlama, } \\
\text { Dönüştürücü Liderlik, İş Özerkliği, İş Performansı }\end{array}$ & $\begin{array}{l}\text { Keywords: Job-Related Anxiety, Scale Adaptation, } \\
\text { Transformational Leadership, Job Autonomy, Job } \\
\text { Performance }\end{array}$ \\
\hline
\end{tabular}

\begin{tabular}{|c|c|}
\hline $\begin{array}{l}\text { Araştırma ve } \\
\text { Yayın Etiği } \\
\text { Beyanı }\end{array}$ & $\begin{array}{l}\text { Bu çalışma 30/04/2021 tarih ve } 05 \text { sayılı Erzincan Binali Yıldırım Üniversitesi İnsan Araştırmaları Etik Kurulu Kararı } \\
\text { Etik Kurul Onay Belgesi ile bilimsel araştırma ve yayın etiği kurallarına uygun olarak hazırlanmıştır. }\end{array}$ \\
\hline $\begin{array}{c}\text { Yazarların } \\
\text { Makaleye } \\
\text { Olan Katkıları }\end{array}$ & Çalışmanın tamamı iki yazar ile birlikte/bölümleri yazarlara paylaştırılarak oluşturulmuştur. \\
\hline Çıkar Beyanı & Yazarlar açısından ya da üçüncü taraflar açısından çalışmadan kaynaklı çıkar çatışması bulunmamaktadır. \\
\hline
\end{tabular}

1 Öğr. Gör., Erzincan Binali Yıldırım Üniversitesi, Meslek Yüksekokulu, Ulaştırma Hizmetleri Bölümü, emre.gul@erzincan.edu.tr

${ }^{2}$ Doç. Dr., Erzincan Binali Yıldırım Üniversitesi, Ali Cavit Çelebioğlu Sivil Havacılık Yüksekokulu, Havacılık Yönetimi Bölümü, dkocak@erzincan.edu.tr 


\section{Giriş}

Son kırk yılda hızlı bir şekilde değişen müşteri beklentilerinin karşılanması ve artan çevresel belirsizliklerin olumsuz etkilerinin azaltılması örgütsel performansın önemli belirleyicileri olmuştur (Pollitt, 2018: 170). Hızla değişen ve giderek daha karmaşık bir hale gelen çevresel belirsizliklerin azaltılmasında ve örgütün amaçlarına ulaşmasında liderlerin örgüt üyeleri ile olan ilişkileri son derece büyük bir öneme sahiptir (Martin vd., 2016: 68-69). Günümüzde liderlerin örgütün hedeflerini yerine getirmek için çalışanların resmi görev tanımlarının ötesinde performans göstermelerini sağlamaya ihtiyaçları vardır (Grant ve Sumanth, 2009: 932). Bu nedenle liderlik tarzının örgütün ve çalışanların performanslarını etkileyen önemli bir faktör olduğu söylenebilir (Manzoor vd., 2019: 4). Yapılan araştırmalar bazı liderlik tarzlarının (örneğin işlemsel liderlik) çalışanların performanslarını olumsuz olarak etkileyerek azalttı̆̆ını (Al Khajeh, 2018; Mackenzie vd., 2001) bazı liderlik tarzlarının ise (örneğin; dönüştürücü liderlik, mütevazı liderlik) çalışanların performanslarını olumlu olarak etkileyerek artırdığını ortaya çıkarmıştır ( Lai vd., 2020; Vigoda-Gadot, 2007).

Dönüştürücü liderler bir kuruluşun üyelerinin temel tutum ve algılarını etkileyerek, örgütün hedeflerine ulaşmasında ortak bir zihniyet yaratırlar (Bass, 1999: 10). Dönüştürücü liderler ayrıca çekici bir vizyon yaratan, takipçilerini karar verme süreçlerine dahil eden ve onları yaratıcı düşünme konusunda teşvik eden liderlerdir. Son otuz yıl içerisinde dönüştürücü liderliğin sonuçlarının araştırıldığı çok sayıda teorik ve ampirik çalışma yapılmıştır (Zhu ve Akhtar, 2014). Araştırmacılar (örneğin; Katou, 2015; Lai vd., 2020; Manzoor vd., 2019) dönüştürücü liderliğin örgütsel performans ve çalışan performansı üzerinde önemli bir etkisinin olduğunu ortaya koymuşlardır. Yapılan araştırmalar dönüştürücü liderin performans üzerinde önemli bir etkisinin olduğunu gösterse de bu etkinin hangi koşullara göre farklılık gösterdiğine yönelik sınırlı sayıda araştırma mevcuttur (García-Morales vd., 2008).

Bu çalışmamızda iş özerkliği dönüştürücü liderlik ve iş performansı arasındaki ilişkide aracı değişken olarak kullanılmıştır. İş özerkliği çalışanın işini yaparken tecrübe ettiği özgürlük ve takdir yetkisi seviyesini ifade eder (Hackman ve Oldham, 1976: 258). Dönüştürücü liderlerin takipçilerini güçlendirdikleri ve onların bireysel ihtiyaçlarını göz önünde bulundurdukları bilinmektedir (Bass, 1985). Önceki araştırmalar (örneğin; Gözükara ve Simşek, 2015; Svendsen vd., 2018) dönüştürücü liderlerin çalışanların işlerini yaparken özerk olmalarına katkıda bulunduklarını ve onları cesaretlendiklerini ortaya koymuşlardır. Dönüştürücü liderliğin iş özerkliği aracıllı̆ı ile iş performansını artırabileceği planlı davranış teorisi (Ajzen, 1991) ve sosyal değişim teorisine (Blau, 1964) göre açıklanabilir. Planlı davranış teorisine göre çalışanların işlerini yaparken özerk olmalarına katkıda bulunan destekleyici davranışlar, onların baskıcı olmayan denetim mekanizması tecrübesini artırarak daha yüksek performans gösterme ihtimallerini artırır (Svendsen vd., 2018: 178). Sosyal değişim teorisine göre çalışanlar yaptıkları işlerde özerkliklerinin artmasına katkıda bulunan liderlere daha yüksek iş performansı göstererek karşılık verme yükümlülükleri hissederler. Bu doğrultuda dönüştürücü liderlerle etkileşim içinde olan çalışanların yaptıkları işte kendilerini daha fazla özerk hissedecekleri ve bunun sonucunda daha yüksek performans ortaya koyacakları ifade edilebilir.

Araştırmacılar (örneğin; Avolio ve Yammarino, 2002; Zhu ve Akhtar, 2014) dönüştürücü liderlik modellerinin formüle edilmesi ve test edilmesinde, düzenleyici değişkenlerin açık bir şekilde dikkate alınması gerektiğini belirtmişlerdir. Bu çağrıyı dikkate alarak araştırmamızda dönüştürücü liderliğin iş performansı üzerindeki dolaylı etkisinde (iş özerkliği aracılığı ile) işle 
ilgili görevlerin yerine getirilmesiyle ilgili bir dizi endişe ve gerginlik duygusu olarak tanımlanan işle ilgili kaygının (Krannitz vd., 2015) düzenleyici değişken olabileceği iddia edilmiştir. Diğer bir ifade ile dönüştürücü liderliğin iş özerkliği aracılığı ile iş performansı üzerindeki dolaylı etkisinin işle ilgili kaygı düşük olduğunda güçlü, yüksek olduğunda ise zayıf olacağı varsayılmıştır. İşle ilgili kaygının düzenleyici değişken olarak modele dâhil edilmesinin temel nedeni çalışanların iş performanslarının işle ilgili kaygılarının farklı seviyelerine göre değişkenlik gösterebileceği yönünde önemli bir bakış açısı sağlamasıdır. Nitekim yapılan araştırmalar (örneğin; Jones ve Sloane, 2016; Mortensen, 2014) işle ilgili kaygısı yüksek olan çalışanların iş performanslarının düşük olan çalışanlara göre daha az olduğu yönündedir.

Mevcut çalışmamızda dönüştürücü liderliğin iş performansı üzerindeki etkisinde iş özerkliğinin aracı ve işle ilgili kaygının düzenleyici rolü incelenerek literatüre birkaç önemli katkıda bulunulmuştur. Bunlardan ilki, Parker ve DeCotiis (1983) tarafından geliştirilen İşle Illgili Kaygı ölçeğinin güvenirlik ve geçerliliği test edilerek Türkçe uyarlamasının yapılması ve böylece söz konusu ölçeğin Türkçe uyarlamasının istatistiksel olarak kullanılabilir olduğunun ortaya konmasıdır. İkinci olarak mevcut araştırmada dönüştürücü liderlik ve iş performansı arasındaki ilişkide farklı değişkenlerin rollerinin incelenmesi gerektiğini belirten önceki araştırmaların (García-Morales vd., 2008; Lai vd., 2020; Manzoor vd., 2019) önerileri dikkate alınarak bu ilişkide iş özerkliğinin aracı rolü incelenmiş ve önceki araştırma bulgularına katkı sağlanmıştır. Son olarak mevcut araştırmada dönüştürücü liderlerin çalışanların iş performanslarını etkili bir şekilde nasıl artırabileceklerine yönelik koşullar tespit edilmiştir (Avolio ve Yammarino, 2002: 18). Bu doğrultuda dönüştürücü liderliğin iş özerkliği aracılığı ile iş performansı üzerindeki dolaylı etkisinin çalışanların işle ilgili kaygılarının seviyesine göre farklııı gösterdiğini ortaya koyarak önceki araştırma bulgularına katkıda bulunmuştur.

\section{Kavramsal Çerçeve ve Hipotezler}

\subsection{Dönüştürücü Liderliğin İş Performansı Üzerindeki Etkisinde İş Özerkliğinin Aracı Rolü}

Bass (1999: 11) dönüştürücü liderliği, "idealleştirilmiş etki (karizma), ilham, entelektüel teşvik veya bireyselleştirilmiş düşünce yoluyla takipçiyi anlık kişisel çıkarların ötesine taşımak" olarak tanımlamıştır. Dönüştürücü liderler, takipçilerini sorumluluk sahibi ve özerk olma konularında motive eder, onları yenilikçi yollar aramaya teşvik eder ve bireylerin kendi kaderlerini tayin etme duygularını geliştirir (Conger ve Kanungo, 1988: 473). Çalışanlar; örgüt içerisinde desteklenir, motive edilir, yöneticisinden ilham alır ve etkin bir şekilde yönetilirlerse, daha yüksek düzeyde işe katılım sağlama ve işte kendilerini memnun hissetme eğiliminde olurlar (Shamir vd., 1993: 578). Dönüştürücü liderlik, çalışanlardan olumlu rol içi ve rol dışı davranışlarını teşvik etmede en etkili liderlik tarzlarından biridir (Mackenzie vd., 2001: 117). Daha önce belirtildiği üzere dönüştürücü liderler, geribildirim sağlayarak, yüksek performans standartları oluşturarak ve daha yaratıcı ve yenilikçi olmayı destekleyerek takipçilerinin resmi görev tanımlarının ötesinde davranış göstermelerine (Yukl, 1999: 288-289) ve böylece daha yüksek iş performansı göstermelerine katkıda bulunurlar (Lai vd., 2020: 2).

Yukarıda da belirtildiği gibi dönüştürücü liderlerin çalışanların iş performansları üzerinde olumlu bir etkisi vardır. Katz (1964) iş performansını, rol içi iş performansı ve yenilikçi iş davranışından oluşan karmaşık bir yapı olarak tanımlamıştır. Çalışanın rol içi iş performansı; iş tanımıyla doğrudan ilişkili olduğu için örgüt tarafından düzenli olarak gözden geçirilirken, yenilikçi iş davranışı ise örgütün iyileştirilmesi için bir iş rolü içinde yeni fikirler üretmeye ve uygulamaya yönelik girişimlerdir (Scott ve Bruce, 1994: 584). Önceki araştırmalar (örneğin, Fuller vd., 1996; Judge vd., 2000) dönüştürücü liderlerin çalışanların yenilikçi iş davranışlarını 
arttırarak iş performanslarının artırılabileceğini ortaya koymuşlardır. Dönüştürücü liderlik ile iş performansı arasındaki pozitif ilişki, yukarıda bahsedilen durumlardan ötürü birçok araştırmacı tarafından ele alınmıştır (örneğin, Buil vd., 2019; Chandrasekara, 2019; Manzoor vd., 2019).

Mevcut çalışmada dönüştürücü liderlerin çalışanların iş performansları üzerindeki olumlu etkisinde iş özerkliğinin aracı rolü olduğu iddia edilmiştir. Hackman ve Oldham (1976: 258) iş özerkliğini, "işin planlanmasında ve yerine getirilmesinde uygulanacak prosedürlerin tespitinde çalışana önemli düzeyde özgürlük, bağımsızlık ve takdir hakkı sağlama derecesi" olarak tanımlamışlardır. Yaptıkları işte yüksek özerkliğe sahip bireyler resmi görev tanımlarında yer almayan sorumlulukları yerine getirme konusunda gönüllü olarak hareket ederler. İş özerkliğine sahip çalışanlar, edindikleri sorumluluk ve sahiplenme duygusuyla yaratıc fikirler ortaya koyar, işle ilgili daha fazla karar verme yetkinliğine ulaşır (Alpkan vd., 2010: 735) ve sorunlar karşısında en iyi çözümü bulma yeteneği kazanırlar (Shalley ve Gilson, 2004: 38).

Organizasyonlarda liderler, örgütü temsil eden bireyler olarak görüldükleri ve çalışanların performansını değerlendirme veya terfileriyle ilgili kararlar alma yetkisine sahip oldukları için çalışanların davranışlarını etkilerler (Lai vd., 2020: 3). Kendilerine destek ve rehberlik sağlanan çalışanlar, verilen görevleri yerine getirirken kendilerini daha fazla özerk hissederler (Jain ve Duggal, 2018: 1035). Çalışanlara yaptıkları işte özerklik verilmesi, liderin kendilerine önem verdiği ve örgüte yaptıkları katkının önemsendiği algısı yaratarak daha yüksek performans göstermelerine katkı sağlar (Allen vd., 2003; Choi vd., 2020). Araştırmacılar (örneğin; Carless vd., 2000; Jain vd., 2018) dönüştürücü liderlerin, çalışanlara sorumluluk alma ve özerk olmaları konularında ilham verdikleri için daha fazla özerklik sunabileceklerini öne sürmüşlerdir. Çalışanlarına daha fazla özerklik sağlayan dönüştürücü liderler, onların üzerindeki psikolojik kontrol algısını azaltarak onların daha mutlu olmalarına ve daha yüksek performans sergilemelerine katkıda bulunurlar (Gilbert vd., 2017: 17-18).

Dönüştürücü liderler çalışanların ihtiyaçlarını ve isteklerini dikkate aldıkları için çalışanlar bu duruma yüksek seviyede performans göstererek karşılık verme yükümlüğü hissederler (Buil vd., 2019: 65). Geçmişteki araştırmalar, çalışanların görev ve sorumluluklarını yerine getirirken özerk bir şekilde hareket edebilmeleri durumunda performanslarının arttığını ortaya koymuştur (Joo vd., 2010; Rhoades ve Eisenberger, 2002). Bu durum sosyal değişim teorisi (Blau, 1964) kapsamında ele alınabilir. Sosyal değişim teorisi bireylerin ikili ilişkilerdeki davranışlarının temelinde birtakım faydalar elde etmelerinin etkili olduğunu öne sürer. Bireyler karşı taraftan faydalar elde ettikçe bu sosyal değişim ilişkisi devam eder (Foa ve Foa, 1974). İ̧̧ özerkliği, dönüştürücü liderlik ve iş performansı arasındaki ilişkide bir tür sosyal değişim (Blau, 1964) mekanizması yaratarak bu ilişkinin güçlenmesine katkıda bulunur. Morgeson vd. (2005) çalışanların işlerini yaparken özerk olmamalarının yüksek performans göstermelerinin önündeki en büyük engellerden birisi olduğunu iddia etmiştir. Dönüştürücü liderler çalışanların yaptıkları işte özerk olmaları konusunda onları teşvik ederek (Pattnaik ve Sahoo, 2021: 4) kendilerini yaptıkları işin sahibi gibi hissetmelerine ve daha yüksek performans göstermelerine katkıda bulunurlar (Abas vd., 2018: 366). Bu çalışmada dönüştürücü liderliğin iş özerkliği aracılığı ile iş performansı üzerinde dolaylı bir etkisinin olduğu iddia edilmiş ve bu doğrultuda aşağıdaki hipotez geliştirilmiştir.

Hipotez 1: İş özerkliği, dönüştürücü liderlik ve iş performansı arasındaki ilişkiye aracılık eder. 


\section{2. İş Özerkliği ve İş Performansı Arasındaki iliş̧kide İşle îlgili Kaygının Düzenleyici Rolü}

Bu çalışmada iş özerkliği ve iş performansı arasındaki ilişkide işle ilgili kaygının düzenleyici rolünün olduğu varsayılmıştır. Algılanan fiziksel veya psikolojik tehlikeye tepki olarak korku, sıkıntı ve huzursuzluk ile hoş olmayan bir duygusal durum olarak tanımlanan kaygı (Taylor vd., 1991: 295); iş yaşamında değerli kaynaklara (örneğin mevki, saygınlık gibi) yönelik bir tehdit durumunda ortaya çıkabilir (Fila ve Eatough, 2018: 155). Ayrıca, kontrol dışı gibi görünen yüksek iş taleplerinin olduğu durumlarda kaygı yaşanmaktadır (Hui ve Sue-Chan, 2018: 666). İ̧̧ kaygısı, çalışanların işleriyle ilgili artan uyarılma, belirsiz bir korku ve güvensizlik hissedebilecekleri endişeli zihinsel durumu yansıtır (Spector vd., 1988: 11-12). İşle ilgili kaygı, işle ilgili görevlerin yerine getirilmesiyle ilgili bir dizi endişe ve gerginlik duygusudur (Baba ve Jamal, 1991; Parker ve DeCotiis, 1983). İşle ilgili kaygı her ne kadar stresle ilişkili bir durum olsa da (Kerr vd., 2009) geçmişte yapılan araştırmalar (örneğin; Cheng ve McCarthy, 2018; Morgan ve Harris, 2015) işle ilgili kaygının iş stresinden farklı olduğunu ifade etmişlerdir. Stres, bireyin tehdit olarak algıladığı dış çevredeki uyarıcılara karşı gösterdiği tepkilerini (örneğin, korku, endişe) ifade ederken, işle ilgili kaygı ise bireyin işini yaparken yaşadığı bir gerginlik durumunu ve stres süreci içinde bir zorlanma belirtisini temsil eder (Bliese vd., 2017: 392).

İşle ilgili kaygı tipik olarak bireysel düzeyde bir yapı olarak incelense de, örgütsel ortamda bireyin işini yapmasına etki eden birtakım faktörlerden (örneğin; takım çalışması, liderlik davranışları, işteki özerklik gibi) etkilenebilir (Mao vd., 2021: 36). Günümüzde çalışanların rol ötesi davranışlarının önemli olduğu iş yaşamında işle ilgili kaygının varlığı çalışanların kendilerinden beklenen asgari görevleri yerine getirmelerinde büyük bir engel yaratır (Lim ve Tai, 2014: 357; McCarthy vd., 2016: 281). Yapılan araştırmalar (örneğin; Brown ve Leigh, 1996; Hobfoll, 1989) örgüt içerisinde gerginlik ve kaygı yaşayan çalışanların performanslarının kaygı yaşamayan çalışanlara göre daha düşük olduğunu ortaya koymuştur. Önceki çalışmalar işle ilgili kaygının iş yerinde zorbalık (Nauman vd., 2019), algılanan terör tehditleri (De Clercq vd., 2017) ile pozitif, öz yeterlilik, iş performansı (De Clercq vd., 2018) ve yaratıcılık (Mao vd., 2021) ile negatif ilişkili olduğunu bulmuşlardır. Önceki araştırmalar (örneğin; Joo vd., 2010) iş özerkliği ile iş performansı arasında pozitif bir ilişki olduğunu ortaya koymuş olsalar da mevcut çalışmada bu ilişkinin şiddetinin işle ilgili kaygının farklı seviyelerine göre değişkenlik gösterebileceği iddia edilmiştir. Diğer bir ifade ile bu çalışmada, iş özerkliğinin iş performansı üzerindeki pozitif etkisinin işle ilgili kaygı yüksek iken zayıf, düşük iken güçlü olduğu öngörülmüş ve doğrultuda aşağıdaki hipotez oluşturulmuştur:

Hipotez 2: Iş̧ özerkliği ile iş performansı arasındaki ilişkide işle ilgili kaygının düzenleyici rolü vardır. Diğer bir ifade ile iş özerkliği ile iş performansı arasındaki pozitif ilişki işle ilgili kaygı yüksek olduğunda zayıf, düşük olduğunda ise güçlüdür.

İşle ilgili kaygının, iş özerkliği ve iş performansı arasındaki ilişkide düzenleyici rolünün olabileceği varsayımı (Hipotez 2), dolaylı etkinin bir düzenleyici değişkenin seviyesiyle ilişkili olduğu şartlı dolaylı etkiyi ifade etmektedir (Muller vd., 2005; Preacher vd., 2007). Dolayısıyla çalışanların işle ilgili kaygılarının dönüştürücü liderliğin iş özerkliği aracılığı ile iş performansı üzerindeki dolaylı etkisine şartlı olarak etki etmesi olasıdır. Başka bir ifade ile mevcut çalışmada dönüştürücü liderliğin iş performansı üzerindeki dolaylı etkisi (iş özerkliği aracılığı ile) işle ilgili kaygı düşük iken güçlü, yüksek iken zayıf olduğu ileri sürülmüş ve aşağıdaki hipotez kurulmuştur: 
Hipotez 3: Dönüştürücü liderliğin iş özerkliği aracılığıyla iş performansı üzerindeki pozitif ve dolaylı etkisinde işle ilgili kaygının düzenleyici rolü vardır. Şöyle ki dolaylı etkinin şiddeti işle ilgili kaygı yüksek iken zayıf, düşük olduğunda ise güçlüdür.

Şekil 1: Araştırma Modeli

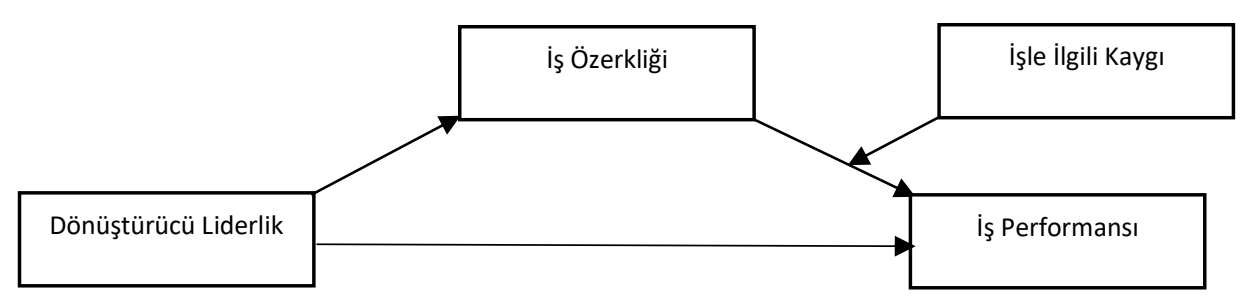

3. Yöntem

Araştırmanın amaçları iki çalışmada gerçekleştirilmiştir. Birinci çalışmada işle ilgili kaygı ölçeğinin Türkçe uyarlaması yapılmış, ikinci çalışmada ise araştırma hipotezleri test edilmiştir.

\section{1. Çalışma 1: Yöntem}

\subsection{1. Örneklem ve Prosedür}

Mevcut çalışmada öncelikli olarak Parker ve DeCotiis (1983) tarafından geliştirilen İşle illgili Kaygı Ölçeğinin Türkçe uyarlamasını yapmak amacıyla Türkiye'de Erzincan ilinde hizmet veren bir hastanede görev yapan 159 hemşireden anket yöntemi kullanılarak veri toplanmıştır. Anketler katılımcılara gizliliklerinin garanti edildiğini belirten bir e-mail ile iletilmiştir. Yollanan anketlere geri dönüş oranı yüzde 66,3'tür. Katılımcılara ait özellikler incelendiğinde büyük çoğunluğunun $(\% 69,8)$ kadın olduğu görülmüştür. Yaşlarına göre katılımcıların büyük çoğunluğunun $(\% 42,8) 24-28$ yaş aralığında olduğu ve büyük çoğunluğunun $(\% 45,9)$ iki yıl ve altı tecrübeye sahip oldukları görülmüştür.

\subsection{2. İşle İlgili Kaygı Ölçeği}

Çalışanların işle ilgili kaygı düzeylerini ölçmek için Parker ve DeCotiis (1983) tarafından geliştirilen 5 madde ve tek boyutlu "İ̧̧le ilgili Kaygı Ölçeği”" kullanılmıştır. Ölçekte "Işim yüzünden kendimi huzursuz veya gergin hissetmekteyim", "İşimi olması gerekenden daha fazla kafama takıyorum" şeklinde ifadeler bulunmaktadır. Ölçekteki her bir madde 5'li Likert tipindedir (1-kesinlikle katılmıyorum ve 5-kesinlikle katılıyorum).

\subsection{3. İ̧̧le İlgili Kaygı Ölçeğinin Türkçeye Çevirisi}

Farklı dilde geliştirilmiş bir ölçeğin uyarlamasını yapabilmek için birtakım adımların izlenmesi gerekmektedir (Brislin vd., 1973). Mevcut araştırmada uyarlaması yapılan işle ilgili kaygı ölçeği, Parker ve DeCotiis (1983) tarafından geliştirilmiş olup, beş maddeden oluşmaktadır. Araştırmacılar tarafından orijinal hali İngilizce dilinde hazırlanmış olan ölçeğin, iki dile de (Türkçe ve İngilizce) hâkim olan iki uzman tarafından Türkçe çevirisi yapılmıştır. Sonrasında, tercümesi yapılan ölçek soruları farklı iki dilbilimci tarafından Ingilizceye geri çevrilmiş ve orijinal haliyle karşılaştırılmıştır. Ardından, sosyal bilimler alanında yetkin üç öğretim üyesinden görüş alınmış olup ölçeğin anlaşılırlığı, yapısı ve bağlama uyumluluğu incelenmiştir. Son olarak, alanda uzman iki öğretim üyesine ölçeğin son hali kontrol ettirilip onaylatılmıştır. Tüm bu adımlar sonucunda, işle ilgili kaygı ölçeğinin Türkçe çevirisinin uygun olduğu kararlaştırılmıştır. 


\section{2. Çalışma 1: Bulgular}

\subsection{1. İşle İlgili Kaygı Ölçeğine Ait Güvenirlilik Analizi}

İşle ilgili kaygı ölçeğinin güvenirlilik analizi için ölçeğin içsel tutarlılı̆ını gösteren Cronbach Alfa katsayısı hesaplanarak incelenmiştir. İşle ilgili kaygı ölçeğinin güvenirliliğini belirlemek amacıyla yapılan analizler neticesinde ortaya çıkan bulgular Tablo 1'de özetlenmiştir.

Tablo 1: İşle İlgili Kaygı Ölçeğine Ait Güvenirlilik Analizi Sonuçları

\begin{tabular}{ccccccc}
\hline Madde No & $\begin{array}{c}\text { Aritmetik } \\
\text { Ortalama }\end{array}$ & $\begin{array}{c}\text { Standart } \\
\text { Sapma }\end{array}$ & $\begin{array}{c}\text { Madde } \\
\text { Silinirse } \\
\text { Ölçeğin } \\
\text { Ortalaması }\end{array}$ & $\begin{array}{c}\text { Madde } \\
\text { Silinirse } \\
\text { Ölçeğin } \\
\text { Varyansı }\end{array}$ & $\begin{array}{c}\text { Düzeltilmiş } \\
\text { Madde Toplam } \\
\text { Puan } \\
\text { Korelasyonu }\end{array}$ & $\begin{array}{c}\text { Madde Silinirse } \\
\text { Ölçeğin } \\
\text { Cronbach Alfa } \\
\text { Katsayısı }\end{array}$ \\
\hline IK1 & 3,26 & 1,23 & 11,45 & 16,13 & 0,72 & 0,81 \\
IK2 & 3,25 & 1,19 & 11,46 & 16,18 & 0,74 & 0,80 \\
IK3 & 2,98 & 1,17 & 11,73 & 16,27 & 0,69 & 0,82 \\
IK4 & 2,66 & 1,24 & 12,05 & 16,08 & 0,71 & 0,81 \\
IK5 & 2,55 & 1,38 & 12,16 & 17,16 & 0,50 & 0,87 \\
\hline \multirow{8}{*}{ GENEL } & Aritmetik & Standart & & Varyans & & Cronbach Alfa \\
& Ortalama & Sapma & & 24,82 & & 0,86 \\
\hline
\end{tabular}

Not: IK= İ̧le ilgili kaygı

Tablo 1'deki bulgular, bu maddelerden herhangi birinin ölçekten silinmesi durumunda Cronbach Alfa katsayısı değerinde önemli seviyede bir değişiklik olmayacağını göstermektedir. Bu sebeplerden dolayı ölçekten herhangi bir maddenin çıkarılmasına ihtiyaç duyulmamıştır. Ölçeğin Cronbach Alfa değerinin 0,86 olarak çıkması güvenirliliğinin yüksek olduğunu göstermektedir.

Ölçekte yer alan maddelerin birbirleriyle olan ilişkilerinin belirlemesi kapsamında maddeler arası korelasyon değerleri de analiz edilmiştir. Bir madde üstündeki puanların ölçekte yer alan diğer bütün maddelere ait puanlar ile ne derece ilişkili olduğu, maddeler arası korelasyon değerleri ile incelenmektedir. Yapılan analizler neticesinde ortaya çıkan bulgular Tablo 2'de özetlenmiştir.

Tablo 2: Maddeler Arası Korelasyon Değerleri

\begin{tabular}{cccccc}
\hline Değişkenler & $\mathbf{1}$ & $\mathbf{2}$ & $\mathbf{3}$ & $\mathbf{4}$ & $\mathbf{5}$ \\
\hline IK1 & 1 & & & & \\
IK2 & $0,73^{* *}$ & 1 & & & \\
IK3 & $0,60^{* *}$ & $0,63^{* *}$ & 1 & 1 & 1 \\
IK4 & $0,59^{* *}$ & $0,62^{* *}$ & $0,62^{* *}$ & $0,47^{* *}$ & 1 \\
IK5 & $0,40^{* *}$ & $0,42^{* *}$ & $0,40^{* *}$ & & \\
\hline
\end{tabular}

Not: ${ }^{* *} \mathrm{p}<0,01$; IK= Işsle ilgili kayg।

Tablo 2' deki değerler incelendiğinde 0,40 ile 0,73 aralığında maddeler arası korelasyon değerlerinin olduğu görülmektedir. Bulgulara göre, maddelerin birbirleriyle pozitif yönde bir ilişki içerisinde olduğu söylenebilir.

Güvenirlilik ve korelasyon analizlerinden sonra faktör bazlı ayırt etme aşamasına geçilmiştir. Ölçeğe ait \%27'lik üst ve alt grupların skorları arasında anlamlı düzeyde bir farklıığın olup olmadığını tespit etmek amacıyla bağımsız t-testi uygulanmıştır. Bu analizin yapılma amacı, her maddeye ait verilmiş olan yanıtın üst ve alt gruplar arasında farklılığın olup olmadığını yani ayıt edebilme gücünü belirlemektir. Yapılan analizler neticesinde ortaya çıkan bulgular Tablo 3' de özetlenmiştir. 
Tablo 3: Maddelere i̇lişkin Üst ve Alt Grup Ortalamalarına Dair Bağımsız t Testi Sonuçları

\begin{tabular}{cccccc}
\hline Madde No & Grup & Ort. & Std. Sapma & t & p \\
\hline \multirow{2}{*}{ IK1 } & Üst grup & 4,45 & 0,63 & 17,65 & 0,00 \\
& Alt grup & 1,92 & 0,67 & 17,65 & 0,00 \\
IK2 & Üst grup & 4,30 & 0,60 & 16,05 & 0,00 \\
& Alt grup & 1,88 & 0,77 & 16,05 & 0,00 \\
IK3 & Üst grup & 4,19 & 0,77 & 14,17 & 0,00 \\
& Alt grup & 1,78 & 0,78 & 14,17 & 0,00 \\
IK4 & Üst grup & 4,21 & 0,60 & 22,08 & 0,00 \\
& Alt grup & 1,52 & 0,50 & 22,08 & 0,00 \\
IK5 & Üst grup & 3,88 & 0,99 & 13,14 & 0,00 \\
& Alt grup & 1,38 & 0,73 & 13,14 & 0,00 \\
\hline
\end{tabular}

Not: $n=159 ;$ IK= İşle ilgili kayg।

Tablo 3 incelendiğinde, tüm gruplar için ortaya çıkan farklılıkların anlamlı olduğu görülmektedir $(p<0,01)$. Elde edilen verilere göre, ölçekte yer alan maddelerin birbirlerinden bağımsız oldukları sonucuna ulaşılmıştır.

\subsection{2. İşle İlgili Kaygı Ölçeğine Ait Keşfedici Faktör Analizi}

İşle ilgili kaygı ölçeğinin güvenirlilik analizinin yapılmasının ardından geçerliliğini belirlemek amacıyla keşfedici faktör analizi (KFA) uygulanmıştır. Yapılan analizler neticesinde ortaya çıkan veriler Tablo 4' de verilmiştir.

Tablo 4: Keşfedici Faktör Analizi Sonuçları

\begin{tabular}{|c|c|c|c|c|c|}
\hline Madde No & $\begin{array}{l}\text { Faktör } \\
\text { Yükleri }\end{array}$ & Özdeğer & $\begin{array}{c}\text { Açılanan } \\
\text { Varyans } \\
(\%) \\
\end{array}$ & $\begin{array}{c}\text { Toplam } \\
\text { Varyans } \\
(\%) \\
\end{array}$ & Cronbach Alfa \\
\hline $\begin{array}{l}\text { IK1. İşim yüzünden kendimi huzursuz } \\
\text { veya gergin hissetmekteyim. }\end{array}$ & 0,84 & \multirow{5}{*}{3,23} & \multirow{5}{*}{64,74} & \multirow{5}{*}{64,74} & \multirow{5}{*}{0,86} \\
\hline $\begin{array}{l}\text { IK2. İşimi olması gerekenden daha fazla } \\
\text { kafama takıyorum. }\end{array}$ & 0,86 & & & & \\
\hline $\begin{array}{l}\text { IK3. Çoğu zaman işim beni çileden } \\
\text { çıkarır. }\end{array}$ & 0,82 & & & & \\
\hline $\begin{array}{l}\text { IK4. Bazen işimi düşündüğümde } \\
\text { göğsümde bir sıkışma hissederim. }\end{array}$ & 0,83 & & & & \\
\hline $\begin{array}{l}\text { IK5. İşten izin aldığımda kendimi suçlu } \\
\text { hissederim. }\end{array}$ & 0,64 & & & & \\
\hline \multicolumn{6}{|c|}{$\begin{array}{c}\text { KMO }=0,84 \\
\text { Küresellik Derecesi (Bartlett's)= 365,30 } \\
p=0,00\end{array}$} \\
\hline
\end{tabular}

Not: IK= İ̧̧le ilgili kaygı

Ölçeğin faktör analizine uygun olup olmadığını yorumlayabilmek için Kaiser-Meyer-Olkin (KMO) ve Bartlett's Küresellik testi sonuçlarının ele alınması gerekmektedir. Tablo 4 incelendiğinde KMO değerinin 0,84 olarak çıkması $(K M O>0,60)$ faktör analizi için örneklemin yeterli büyüklükte olduğunu göstermektedir. Yine tablodan hareketle Bartlett's Küresellik testinin $(365,30 ; p=0,00)$ anlamlı olması $(p \leq 0,05)$ ise verilerin faktör analizine uygun olduğunu göstermektedir. Ayrıca tablodaki sonuçlar incelendiğinde ölçekteki her bir maddenin faktör yüklerinin 0,40 'tan yüksek olduğu görülmektedir. Ölçekte yer alan her bir maddenin faktör yüklerinin 0,64 ile 0,86 arasında değiştiği görülmektedir. Yani bu sonuç, maddelerin faktörü nitelediğini ortaya koymaktadır. Analiz sonucuna göre, ölçekte bulunan toplam beş maddenin özdeğeri 1'den yüksek olan tek bir maddede birleştiği görülmektedir. Analizler sonucunda 
birinci faktörden sonra gözle görünür bir şekilde kırılma meydana gelmiştir. Bu maddeler toplam varyansın \%64,74' ini açıklamaktadır.

Yukarıda bahsedilen tüm analizler neticesinde, Parker ve DeCotiis (1983) tarafından geliştirilen tek boyuttan oluşan toplam 5 maddeli işle ilgili kaygı ölçeğinin Türkçe uyarlanmasında yapılan keşfedici faktör analizi sonuçları incelendiğinde ölçeğin Türkçe alanyazında orijinal halinde de belirtildiği üzere tek boyutlu olarak ele alınmasının araştırmacılar için faydalı olacağı kanaatine varılmıştır.

\subsection{3. İşle İlgili Kaygı Ölçeğine Ait Doğrulayıcı Faktör Analizi}

İşle ilgili kaygı ölçeğinde yer alan maddelerin keşfedici faktör analizi sonucunda oluşan faktör yapısının uyumunu belirlemek amacıyla doğrulayıcı faktör analizi (DFA) yapılmıştır. Yapılan analiz neticesinde işle ilgili kaygı ölçeğine ait uyum iyiliği değerleri incelendiğinde; $\mathrm{CMIN} / \mathrm{DF}=1,98, \mathrm{NFI}=0,97, \mathrm{CFI}=0,98, \mathrm{IFI}=0,98, \mathrm{TLI}=0,97, \mathrm{GFI}=0,97$ ve $\mathrm{AGFI}=0,92$ değerlerinin iyi uyum aralığında, RMSEA $=0,07$ değerinin ise kabul edilebilir uyum aralığında oldukları görülmektedir. İşle ilgili kaygı ölçeğine ait doğrulayıcı faktör analiz sonuçları ele alındığında ölçeğin tek faktörlü yapıya uyum gösterdiği tespit edilmiştir.

\section{3. Çalışma 2: Yöntem}

\subsection{1. Örneklem ve Prosedür}

İkinci çalışma kapsamında dönüştürücü liderlik ile iş performansı arasındaki ilişkide iş özerkliğinin aracı ve işle ilgili kaygının düzenleyici etkisini incelemek amacıyla Türkiye' de hizmet sektöründe faaliyet gösteren özel bir şirkette çalışan 237 katılımcıdan gönüllülük ve gizlilik ilkesi doğrultusunda anket yoluyla veri elde edilmiştir. Anketler katılımcılara sosyal medya aracılığı ile iletilmiş ve katılım oranı 69,7 olarak tespit edilmiştir. Katılımcıların \%54'ü kadın, $\% 42,6$ 'sı 34 yaş ve üzeri ve $\% 36,7^{\prime}$ si 2 yıl ve altı tecrübeye sahiptir.

\subsection{2. Ölçekler}

Dönüştürücü Liderlik Ölçeği: Dönüştürücü liderlik Carless vd. (2000) tarafından geliştirilen 7 madde ve tek boyutlu "Dönüştürücü Liderlik Ölçeği” kullanılarak ölçülmüştür. Ölçekte "Yöneticim, işgörenlerine karşı açıktır ve vizyonu onlarla paylaşır", "Yöneticim işgörenleri cesaretlendirir ve onları takdir eder" şeklinde ifadeler bulunmaktadır. Katılımcılardan ilk amirlerinin liderlik davranışlarını $1=$ kesinlikle katılmıyorum ve $5=$ kesinlikle katılıyorum arasında değişen $5^{\prime}$ li Likert ölçeğine göre değerlendirmeleri istendi.

İ̧ Özerkliği Ölçeği: Çalışanların örgütteki iş özerkliği seviyelerini tespit etmek için Hackman ve Oldham (1980) tarafından geliştirilen üç madde ve tek boyutlu "İ̧̧ Özerkliği" ölçeği kullanılmıştır. Ölçekte "İşimi nasıl yapacağıma kendim karar verebilirim.", "İşimi nasıı yapacağım konusunda önemli ölçüde bağımsızlığa ve özgürlüğe sahibim." şeklinde ifadeler bulunmaktadır. Katılımcılardan işteki özerkliklerini değerlendirmeleri için $1=$ kesinlikle katılmıyorum ile 5 = kesinlikle katılıyorum arasında değişen $5^{\prime} l i$ Likert ölçeğine göre cevaplamaları istendi.

İ̧ Performansı Ölçeği: Çalışanların iş performanslarını ölçmek için Kirkman ve Rosen (1999), Sigler ve Pearson (2000) tarafından geliştirilen dört madde ve tek boyutlu "îş Performansı" ölçeği kullanılmıştır. Ölçekte "Görevlerimi tam zamanında gerçekleştiririm", "İşle ilgili hedeflerimi fazlasıyla yerine getiririm" şeklinde ifadeler bulunmaktadır. Katılımcılar ölçek maddelerine 1 = kesinlikle katılmıyorum ile 5 = kesinlikle katılıyorum arasında değişen 5 'li Likert tipi bir ölçeğe göre yanıt verdiler. 
Kontrol Değişkenleri: Önceki araştırmalar (örneğin; Deadrick ve Gardner, 2008; Lai vd., 2020; Masa'deh vd., 2016) bazı demografik değişkenlerin çalışanların iş performans düzeylerini etkilediğini ortaya koymasından dolayı mevcut araştırmada cinsiyet (1= kadın, $2=$ erkek), yaş ( $1=23$ ve altı, $2=24-28,3=29-33,4=34$ ve üzeri) ve kıdem ( $1=2$ yıl ve altı, 2= 3-6 yıl, 3= 7-10 yıl, 4= 11 yıl ve üstü) gibi değişkenler kontrol edilmiştir.

\section{4. Çalışma 2: Bulgular}

\subsubsection{Betimleyici İstatistikler}

Tablo 5 ölçeklere ait ortalama, standart sapma ve ölçekler arası korelasyon değerlerini göstermektedir. Sonuçlar, dönüştürücü liderliğin iş özerkliği $(r=0,31, p<0,01)$ ve iş performansı ( $r=0,23, p<0,01$ ) ile pozitif ilişkili olduğu yönündedir. Ayrıca iş özerkliği ile iş performansı $(r=0,48, p<0,01)$ arasında pozitif bir ilişki olduğu görülmüştür.

Tablo 5: Ortalama, Standart Sapma ve Korelasyon Değerleri

\begin{tabular}{lccccccccc}
\hline Ölçekler & $\mathbf{M}$ & $\mathbf{S S}$ & $\mathbf{1}$ & $\mathbf{2}$ & $\mathbf{3}$ & $\mathbf{4}$ & $\mathbf{5}$ & $\mathbf{6}$ & $\mathbf{7}$ \\
\hline Cinsiyet & 1,46 & 0,49 & - & & & & & & \\
Yaş & 2,94 & 1,03 & 0,06 & - & & & & & \\
Kıdem & 2,22 & 1,16 & 0,10 & $0,67^{* *}$ & - & & & & \\
DL & 3,59 & 1,12 & $-0,04$ & $-0,26^{* *}$ & $-0,23^{* *}$ & $(0,95)$ & & & \\
IO & 3,89 & 0,82 & $-0,02$ & 0,05 & 0,01 & $0,31^{* *}$ & $(0,79)$ & & \\
IK & 2,61 & 0,87 & 0,04 & 0,06 & 0,07 & $-0,35^{* *}$ & $-0,26^{* *}$ & $(0,76)$ & \\
IP & 4,11 & 0,76 & $-0,06$ & 0,01 & 0,02 & $0,23^{* *}$ & $0,48^{* *}$ & $-0,08$ & $(0,88)$ \\
\hline
\end{tabular}

Not: $\mathrm{n}=237 ;{ }^{* *} \mathrm{p}<0,01 ; \mathrm{SS}=$ Standart sapma; $\mathrm{M}=$ Ortalama; $\mathrm{DL}=$ Dönüştürücü liderlik; IO= İ̧̧ özerkliği; IK= Iş̧le ilgili kaygı; IP = İş performansı; Değişkenlerin içsel tutarlılıkları hakkında bilgi veren Cronbach Alpha değerleri parantez içerisinde verilmiştir.

\subsection{2. Ölçüm Modelleri}

Araştırma hipotezlerinin test edilmesinden önce AMOS 24 kullanılarak araştırma değişkenlerinin ayırt edici geçerliliğinin incelenmesi için bir dizi doğrulayıcı faktör analizi yapılmıştır. Maksimum olabilirlik yöntemi kullanılarak ölçeklerin öngörülen yapılarının toplanan veri ile desteklenip desteklenmediği alternatif modeller stratejisi ile analiz edilmiştir (Anderson ve Gerbing, 1988: 411). Bunun için ölçüm modeli (dönüştürücü liderlik, iş özerkliği, işle ilgili kaygı ve iş performansından oluşan dört faktörlü model), $X^{2}$ farklılık testleri kullanılarak beş alternatif model ile karşılaştırılmıştır. Tablo 6 'da verilen sonuçlar dört faktörlü ölçüm modelinin model uyum indekslerinin diğer modellere göre daha iyi olduğunu göstermektedir $\left(X^{2}(142)=277, p<0,01, \operatorname{RMSEA}=0,06, \mathrm{CFI}=0,95, \mathrm{SRMR}=0,06\right)$. Bu sonuçlar doğrultusunda mevcut çalışmadaki dört faktörlü yapının ayırt edici geçerliliğinin olduğu söylenebilir. 
Tablo 6: Ölçüm Modellerinin Karşılaştırılması

\begin{tabular}{|c|c|c|c|c|c|}
\hline & \multirow{2}{*}{$x 2(d f)$} & \multirow{2}{*}{ RMSEA } & \multirow{2}{*}{ CFI } & \multirow{2}{*}{ SRMR } & \multirow{2}{*}{$\begin{array}{c}\text { Model karşılaştırması } \\
\Delta X^{2}(\Delta \mathrm{df})\end{array}$} \\
\hline & & & & & \\
\hline Ölçüm modeli, 4 faktörlü model & $277(142)$ & 0,06 & 0,95 & 0,06 & - \\
\hline Model 1, 3 faktörlü modelạ & $535(145)$ & 0,11 & 0,87 & 0,12 & $258(3)$ \\
\hline Model 2, 3 faktörlü model ${ }^{b}$ & $553(145)$ & 0,11 & 0,87 & 0,11 & $276(3)$ \\
\hline Model 3, 3 faktörlü model ${ }^{c}$ & $518(145)$ & 0,11 & 0,88 & 0,12 & $241(3)$ \\
\hline Model 4, 2 faktörlü model ${ }^{\mathrm{d}}$ & $791(147)$ & 0,14 & 0,80 & 0,14 & $514(5)$ \\
\hline Model 5, 1 faktörlü model ${ }^{\mathrm{e}}$ & $1214(148)$ & 0,18 & 0,66 & 0,17 & $937(6)$ \\
\hline
\end{tabular}

Not: $\mathrm{n}=237 ; \chi 2 / \mathrm{df}=$ Ki-Kare Uyum Testi; RMSEA=Yaklaşık Hataların Ortalama Karekökü; CFI= Karşılaştırmalı Uyum İndeksi; SRMR=Standartlaştırılmış Ortalama Hataların Karekökü; $\Delta \chi 2=$ Ki-Kare farkı; $\Delta \mathrm{df}=$ Serbestlik Derecesi Farkı; 3 faktörlü modela (Model 1)= Dönüştürücü liderlik ve iş özerkliği tek faktörde birleştirildi; 3 faktörlü model ${ }^{\text {b }}$ (Model 2)= Dönüştürücü liderlik ve işle ilgili kaygı tek faktörde birleştirildi; 3 faktörlü model ${ }^{c}$ (Model 3)= İş özerkliği ve işle ilgili kaygı tek faktörde birleştirildi; 2 faktörlü model ${ }^{d}$ (Model 4)= Dönüştürücü liderlik, iş özerkliği ve işle ilgili kaygı tek faktörde birleştirildi; Harman'ın tek faktörlü modelie (Model 5)= Bütün değişkenler tek faktörde birleştirildi.

\subsection{Hipotezlerin Test Edilmesi}

Araştırma hipotezleri iki adımda test edilmiştir. Birinci adımda dönüştürücü liderliğin iş performansı üzerindeki etkisinde iş özerkliğinin aracılık etkisi basit aracılık modeli ile test edilmiştir (Hipotez 1). İkinci adımda ise düzenleyici değişken olan işle ilgili kaygı modele dahil edilerek iş özerkliğinin iş performansı üzerindeki etkisinin (Hipotez 2) ve dönüştürücü liderliğin iş performansı üzerindeki iş özerkliği aracılığı ile aktarılan dolaylı etkisinin (Hipotez 3) işle ilgili kaygının düşük ve yüksek seviyelerine göre farklılaşıp farklılaşmadığı test edilmiştir.

Aracı rolün analiz edilmesi: Dönüştürücü liderlik ile iş performansı arasındaki ilişkide iş özerkliğinin aracı rolünü tespit etmek amacıyla hiyerarşik regresyon analizi yapılmıştır (Hipotez 1). Yapılan analizlerde aracı rolün anlamlılı̆ı Bootstrap tekniği ile kontrol edilmiştir. Bu teknik sayesinde elde edilen güven aralıkları, dolaylı etkinin asimetrik ve normal olmayan örneklem dağıımının ortaya çıkardığı güç problemlerinin etkisini yok edebilir (Preacher ve Hayes, 2008). Bu nedenlerden ötürü aracı rolün test edilmesinde Bootstrap güven aralıklarının elde edilmesini sağlayan ve Hayes (2017) tarafından geliştirilen Process Macro (SPSS için) programı kullanılmıştır.

Tablo 7: Aracı Etkiye iliş̧kin Regresyon Analizi Sonuçları

\begin{tabular}{|c|c|c|c|c|}
\hline & \multicolumn{4}{|c|}{ İş performansı } \\
\hline & $B$ & SE & $t$ & $p$ \\
\hline Cinsiyet & $-0,07$ & 0,08 & $-0,85$ & 0,39 \\
\hline Yaş & $-0,03$ & 0,05 & $-0,55$ & 0,57 \\
\hline Kıdem & 0,04 & 0,05 & 0,96 & 0,33 \\
\hline DL' nin direkt etkisi & 0,06 & 0,04 & 1,59 & 0,11 \\
\hline İş Özerkliği & 0,41 & 0,05 & 7,39 & 0,00 \\
\hline \multirow[t]{2}{*}{ DL'nin toplam etkisi } & 0,17 & 0,04 & 3,85 & 0,00 \\
\hline & Etki & SE & EDGA\%95 & EYGA\%95 \\
\hline $\begin{array}{l}\text { DL'nin IO aracılığıyla IP üzerindeki } \\
\text { dolaylı etkisi }\end{array}$ & 0,10 & 0,03 & 0,04 & 0,18 \\
\hline
\end{tabular}

Not: $n=237$; SE=Standard hata; Bootstrap örneklem boyutu = 5.000; EDGA=En Düşük Güven Aralığı; EYGA= En Yüksek Güven Aralığı; $\mathrm{DL}=$ Dönüştürücü liderlik; IP= İş performansı; $I O=$ İş özerkliği

Aracı role ilişkin regresyon analizi sonuçları Tablo 7'de verilmiştir. Sonuçlar dönüştürücü liderliğin iş özerkliği aracılığı ile iş performansı üzerindeki dolaylı etkisinin anlamlı olduğunu 
göstermektedir $(B=0,10, S E=0,03)$. Fakat yukarıda da belirtildiği gibi dönüştürücü liderliğin iş performansı üzerinde (iş özerkliği aracılığı ile) dolaylı bir etkisinin olduğunun söylenebilmesi için bootstrap güven aralıklarının incelenmesi gerekir. Sonuçlar incelendiğinde dolaylı etkiye ait bootstrap güven aralığı değerlerinin (\%95 EDGA-EYGA =0,04 ile 0,18) sıfır içermedikleri için dolaylı etkinin anlamlı olduğu söylenebilir. Böylece Hipotez 1'in tam olarak desteklendiği ifade edilebilir.

Şartı dolaylı etkinin analiz edilmesi: Araştırmada Hipotez 2 (işle ilgili kaygı iş özerkliği ile iş performansı arasındaki ilişkide düzenleyici role sahiptir) ve Hipotez 3'ün (işle ilgili kaygı dönüştürücü liderliğin iş özerkliği aracılığı ile iş performansı üzerindeki dolaylı etkisinde düzenleyici role sahiptir) test edilmesinde SPSS 25 programı ve Process Macro analiz türü kullanılmıştır.

Hipotez 2 ve Hipotez 3'e ait sonuçlar Tablo 8'de verilmiştir. Araştırmada öncelikle iş özerkliği ile iş performansı arasındaki pozitif ilişkinin işle ilgili kaygı arttıkça zayıflayacağı, azaldıkça güçleneceği öngörülmüştür (Hipotez 2).

Tablo 8: Şartlı Dolaylı Etkiye illişkin Regresyon Analizi Sonuçları

\begin{tabular}{|c|c|c|c|c|}
\hline & \multicolumn{2}{|c|}{ İş performansı } & \multirow[b]{2}{*}{$t$} & \multirow[b]{2}{*}{ p } \\
\hline & $B$ & SE & & \\
\hline Cinsiyet & $-0,07$ & 0,08 & $-0,88$ & 0,37 \\
\hline Yaş & $-0,02$ & 0,05 & $-0,50$ & 0,61 \\
\hline Kıdem & 0,04 & 0,05 & 0,86 & 0,38 \\
\hline $\mathrm{DL}$ & 0,08 & 0,04 & 2,01 & 0,04 \\
\hline 10 & 0,43 & 0,05 & 7,78 & 0,00 \\
\hline IK & 0,63 & 0,26 & 2,45 & 0,01 \\
\hline \multirow[t]{2}{*}{ IOxIK } & $-0,14$ & 0,06 & $-2,20$ & 0,02 \\
\hline & \multicolumn{3}{|c|}{ İş özerkliğinin iş performansı üzerindeki şartlı etkisi } & \\
\hline IK & $B$ & SE & $\mathbf{t}$ & $\mathbf{p}$ \\
\hline$-1 S D(-0,87)$ & 0,56 & 0,08 & 6,77 & 0,00 \\
\hline$M(0,00)$ & 0,43 & 0,05 & 7,78 & 0,00 \\
\hline \multirow[t]{2}{*}{$+1 S D(0,87)$} & 0,31 & 0,07 & 4,19 & 0,00 \\
\hline & \multicolumn{3}{|c|}{ İş özerkliğinin şartlı dolaylı etkisi $=M \pm 1 S D$} & \\
\hline IK & Boot dolaylı etki & BootSE & Boot EDGA & Boot EYGA \\
\hline$-1 S D(-0,87)$ & 0,14 & 0,04 & 0,06 & 0,23 \\
\hline$M(0,00)$ & 0,11 & 0,03 & 0,05 & 0,18 \\
\hline$+1 S D(0,87)$ & 0,07 & 0,03 & 0,02 & 0,16 \\
\hline
\end{tabular}

Not: SD=Standart sapma; SE=Standard hata; Bootstrap örneklem boyutu = 5.000; EDGA=En Düşük Güven Aralığl; EYGA= En Yüksek Güven Aralığı; DL= Dönüştürücü liderlik; IP= İş performansı; IO= İş özerkliği; IK= İşle ilgili kaygı

Sonuçlar incelendiğinde iş özerkliği ile işle ilgili kaygı arasındaki etkileşimin (IOxIK) anlamlı olduğu görülmektedir ( $B=-0,14, p=0,02)$. Fakat Hipotez 2'nin tam olarak desteklendiğinin söylenebilmesi için bu etkileşimin yapısının Hipotez 2'ye uygun olması gerekir (Cole vd., 2008). Bunun için öncelikle çoklu doğrusallık problemini azaltmak için bağımsız değişkenler (iş özerkliği ve işle ilgili kaygı) merkezileştirilmiş (Aiken ve West, 1991) ve daha sonra işle ilgili kaygı ölçeğinin düşük ve yüksek standart sapma seviyelerine göre bir düzenleyici etki grafiği çizilmiştir (bkz. Şekil 2). Grafik incelendiğinde iş özerkliği ve iş performansı arasındaki ilişkinin işle ilgili kaygı yüksek iken zayıf ( $B=0,31 ; p<0,01)$, düşük iken güçlü $(B=0,56 ; p<0,01)$ olduğu görülmektedir. 
Şekil 2: İş Özerkliği ile İş Performansı Arasındaki illişkide İşle İlgili Kaygının Düzenleyici Rolü

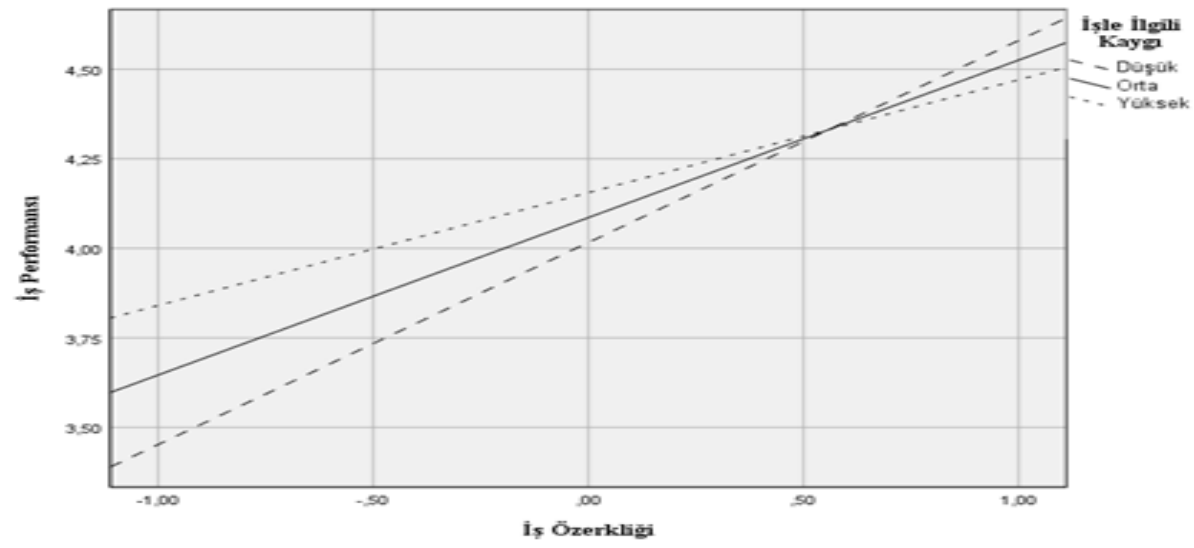

Son olarak dönüştürücü liderliğin iş özerkliği aracılığı ile iş performansı üzerindeki dolaylı etkisinin işle ilgili kaygının seviyesine göre değişip değişmediği test edilmiştir (Hipotez 3). Şartlı dolaylı etkiyi değerlendirmek için Preacher vd. (2007) tarafından geliştirilen bir prosedür kullanılmıştır. İşle ilgili kaygı merkezileştirildiği için (Aiken vd., 1991), işle ilgili kaygının düşük değeri $(-0,87)$ merkezden -1 standart sapma uzaklığındaki değer, yüksek değeri $(0,87)$ ise merkezden +1 standart sapma uzaklığındaki değer ile düşük ve yüksek işle ilgili kaygı olarak tanımlanmıştır (bkz. Tablo 8). Yapılan testler sonucunda işle ilgili kaygının düşük ve yüksek seviyelerine ilişkin şartlı dolaylı etkilerin pozitif ve istatistiksel olarak anlamlı oldukları tespit edilmiştir ( $B=0,14, \% 95$ EDGA-EYGA $=[0,06,0,23]$; $B=0,07$, \%95 EDGA-EYGA = $[0,02,0,16]$ ). Bu sonuçlar Hipotez 3'ün desteklendiği anlamına gelir. Diğer bir ifade ile dönüştürücü liderliğin iş performansı üzerindeki iş özerkliği aracılığı ile aktarılan pozitif dolaylı etkisi işle ilgili kaygı yüksek iken zayıf $(B=0,07, S E=0,03)$ düşük iken güçlüdür $(B=0,14, S E=0,04)$.

\subsection{Tartışma}

Bu çalışma bulguları iş özerkliğinin dönüştürücü liderlik ve iş performansı arasındaki ilişkide aracı rolünün olduğunu göstermiştir. Ayrıca iş özerkliğinin iş performansı üzerindeki etkisinin işle ilgili kaygının farklı seviyelerine göre değişkenlik gösterdiği tespit edilmiştir. Diğer bir ifade ile iş özerkliğinin iş performansı üzerindeki pozitif etkisi işle ilgili kaygısı yüksek olan çalışanlarda zayıf, düşük olan çalışanlarda ise güçlüdür. Sonuçlar ayrıca dönüştürücü liderliğin iş performansı üzerindeki dolaylı etkisinin (iş özerkliği aracılığıyla) işle ilgili kaygı düşük olduğunda güçlü, yüksek olduğunda ise zayıf olduğunu göstermiştir. Bu bulguların teorik ve pratik etkileri ve araştırmanın sınırlıkları aşağıda tartışımıştır.

\subsubsection{Teorik ve Pratik Etkiler}

Bu çalışma bulgularının literatüre birtakım katkıları olmuştur. İlk olarak, mevcut çalışmada Parker ve DeCotiis (1983) tarafından geliştirilen beş maddeli ve tek boyutlu işle ilgili kaygı ölçeğinin Türkçe uyarlaması yapılarak ölçeğin güvenilirliği ve geçerliliği ispatlanmış ve böylece işle ilgili kaygı ölçeğinin Türkiye'de yapılacak çalışmalarda kullanımının uygun olduğu doğrulanmıştır.

Araştırmanın ikinci katkısı dönüştürücü liderlik ve iş performansı ilişkisinde iş özerkliğinin aracı rolünün incelenmesidir. Önceki araştırmalar dönüştürücü liderliğin iş performansını 
artırdığını ortaya koymuş olmalarına rağmen mevcut çalışmada dönüştürücü liderlik ve iş performansı arasındaki ilişkide iş özerkliğinin aracı rolü incelenerek dönüştürücü liderlik ve iş performansı arasındaki ilişkiyi açıklamada bir sosyal değişim mekanizması oluşturulmuştur. Sosyal değişim teorisine (Blau, 1964) göre, dönüştürücü liderliğin örgüt içerinde var olmasıyla çalışanlar daha yüksek performans ortaya koyabilirler (Lai vd., 2020: 2). Diğer bir ifade ile dönüştürücü lider ile etkileşim içinde olan çalışanlar, liderin ilgi ve desteğini hissederler ve böylece daha yüksek iş performansı göstererek liderlerine yani dolayısıyla örgüte karşılık verme yükümlülükleri hissederler. Araştırmacılar (örneğin; Bass ve Avolio, 1990) dönüştürücü liderlerin çalışanlara işlerini yaparken kendilerini özerk hissetmeleri için ilham verdiklerini iddia etmişlerdir. Çalışanlar kendilerine güvenen ve yaptıkları işin tek yetkilisi gibi hissettiren liderlerine daha yüksek iş performansı gösterme konusunda istekli olurlar. Çalışanların yaptıkları işte özerk olmalarına katkı sağlayan liderlik davranışları daha yüksek motivasyonla performans göstermelerini sağlar (Svendsen vd., 2018: 178).

Araştırmanın literatüre son katkısı, dönüştürücü liderliğin iş performansı üzerindeki etkisini açıklamak için işle ilgili görevlerin yerine getirilmesiyle ilgili bir dizi endişe ve gerginlik duygusu olarak tanımlanan işle ilgili kaygının (Krannitz vd., 2015) modele düzenleyici değişken olarak dâhil edilmesi ve böylece iş performansı literatürüne önemli bir katkıda bulunulmuş olmasıdır. Araştırmacılar (örneğin; Manzoor vd., 2019; Lai vd., 2020; MacKenzie vd., 2001) dönüştürücü liderlik ve performans arasındaki ilişkide farklı değişkenlerin etkileri incelenerek bu ilişkinin hangi şartlarda güçlendiğinin (veya azaldığının) önemli olduğunu belirtmişlerdir. Bu nedenle mevcut çalışmada önceki araştırmacıların önerileri dikkate alınarak çalışmada dönüştürücü liderliğin iş özerkliği aracılığı ile iş performansı üzerindeki dolaylı etkisinde işle ilgili kaygının düzenleyici rolü incelenmiştir. Dönüştürücü liderliğin iş özerkliği aracılığı ile iş performansı üzerindeki dolaylı etkisi beklenildiği gibi işle ilgili kaygının düşük ve yüksek seviyelerine göre farklılaşmıştır. Düşük seviyede işle ilgili kaygı, dönüştürücü liderliğin iş performansı üzerindeki dolaylı etkisini arttırırken yüksek seviyede işle ilgili kaygı bu etkiyi zayıflatmıştır. Bu bulgular doğrultusunda, iş özerkliği yüksek ve işle ilgili kaygısı düşük olan çalışanların örgütün yararına olduğuna inandıkları davranışları (örneğin; iş performansı) gösterme konusunda cesur ve istekli oldukları söylenebilir.

Araştırmada elde edilen bulgular temelinde bazı pratik çıkarımlarda bulunmak mümkündür. Bir örgütün verimliliğini etkileyen faktörler arasında iş performansı önemli bir konuma sahiptir (Vigoda-Gadot, 2007: 664). Bu nedenle, örgütlerin temel ilgi alanlarından birisi, çalışanlarının performansını iyileştirmektir. Mevcut çalışmada ortaya konulduğu üzere, örgüt içerisinde dönüştürücü liderlerin varlığının çalışanların iş özerkliğini etkilediği ve böylece daha yüksek iş performansı gösterdikleri görülmüştür. Yapılan araştırmalar (örneğin; Dias ve Borges, 2017; Shafie vd., 2013) dönüştürücü liderliğin çalışan performansını artırmada en etkili liderliklerden biri olduğunu ortaya koymuştur. Bu nedenle örgüt içerisindeki tüm departmanlarda dönüştürücü liderlik tarzının uygulaması için yöneticiler teşvik edilmelidir. Ayrıca yöneticilerinin önemli dönüştürücü liderlik niteliklerine (örneğin; vizyon sahibi, ilham verici, teşvik edici gibi) sahip olmalarını sağlamak için örgütler tarafından gerekli özen gösterilmelidir. Örneğin örgütlerde yöneticiler için dönüştürücü liderlik eğitimleri verilebilir. Dönüştürücü liderlik olmadan örgütlerin hedeflenen kârlılığı, rekabet avantajını ve kurumsal performansı sürdürmeleri çok zor olacağından, kuruluşların her birimde dönüştürücü liderlere sahip olması gerekmektedir (Lussier ve Achua, 2007). 
Araştırma bulguları liderlerin hem çalışanların performanslarını artırabileceklerini hem de iş özerkliğinin öneminin farkında olmaları gerektiğini ortaya çıkarmıştır. Çalışanların güçlendirilerek yaptıkları işte özerk olmalarının sağlanmasına yönelik stratejiler liderlik gelişim programlarının bir parçası olmalıdır. Önceki araştırmalar (Choi vd., 2020; Zhu ve Akhtar, 2014) bazı stratejilerin çalışanların yaptıkları işte özerkliklerinin artırılmasına katkı sağlayacağını ileri sürmüşlerdir. Örneğin liderler örgüt içerisinde güçlendirme iklimi yaratarak, çalışanlara güven vererek ve ceza yerine ödüllendirme mekanizmasını pekiştirici olarak kullanarak çalışanların özerklik algılarını güçlendirebilirler. Sonuç olarak çalışanların yaptıkları işte özerk olmalarını teşvik etmeyi amaçlayan liderlik programlarının etkinliği, bu iş özerkliğini artırıcı stratejiler dâhil edilerek artırılabilir.

Araştırma bulguları ayrıca dönüştürücü liderlerin çalışanların performanslarını artırmada işle ilgili kaygılarını dikkate almaları gerektiğini doğrulamıştır. Yüksek seviyede işle ilgili kaygıları olan çalışanların yaptıkları işe odaklanmaları zor olacağından performanslarının düşük olması muhtemeldir. Bu nedenle çalışanlara ilham veren, onları motive eden ve onları yaptıkları işin sahibi gibi hissettiren dönüştürücü liderler bu kaygıları azaltarak çalışanların performanslarını artırabilirler. Örgütlerde ayrıca çalışanların işle ilgili kaygılarını azaltmada birtakım stratejiler kullanılabilir. Örneğin, örgütün işe alım süreçleri iyileştirilerek işgören seçim aşamasında işle ilgili kaygısı yüksek olan adaylar elenebilir. Ayrıca birtakım teknikler (örneğin; anket, gözlem, mülakat) kullanılarak çalışanların işle ilgili kaygı seviyeleri ölçülebilir ve gerekli çözüm stratejileri geliştirilebilir.

\subsubsection{Kısıtlılıklar ve Öneriler}

Mevcut çalışmada yukarıda bahsedilen teorik ve pratik katkıların yanında birtakım kısıtlılıklar da söz konusudur. Bunlardan ilki araştırma verilerinin kesitsel yapısından ötürü değişkenler arasındaki ilişkilerin nedenselliğinin tam olarak ortaya konamamasıdır. Gelecekte yapılacak çalışmalarda araştırma verileri boylamsal veri toplama desenine göre elde edilerek araştırma sonuçlarının nedenselliğine ilişkin sonuçlara ulaşılabilir. İkinci olarak her ne kadar verilerde ortak yöntem yanlılığının olmadığı Harman 'ın (1976) tek faktör testi ile kanıtlanmış olsa da, bazı araştırmacılar (örneğin, Podsakoff vd., 2003) bu prosedürün ortak yöntem yanlılığının olmadığına yönelik iddiasının zayıf olduğunu belirtmiştir. Bu nedenle araştırmamızda verilerin sadece tek kaynaktan (yani çalışanlardan) toplanmış olmasından (self-reported) ötürü ortak yöntem yanlılı̆ının (common method bias) olabileceği söylenebilir. Gelecekte yapılacak çalışmalarda veriler farklı kaynaklardan toplanarak incelenebilir. Araştırmacılar (Carayon vd., 1999; Gross, 2017) işle ilgili kaygının kültürlere göre farklılaşabileceğini ileri sürmüşlerdir. Bu anlamda mevcut çalışma bulguları toplulukçu ve belirsizlikten kaçan bir yapıya sahip olan Türkiye'de (Hofstede, 1980) yapılmış olması bakımından işle ilgili kaygı literatürüne önemli bir katkı sağlamıştır. Gelecekte yapılacak çalışmalarda kültür boyutu modele dâhil edilerek daha genel sonuçlara ulaşılabilir. Araştırmanın son kısıtı mevcut araştırmada sadece dönüştürücü liderlik tarzının etkileri incelenmiş olup farklı liderlik tarzları dikkate alınmamış olmasıdır. Gelecekte yapılacak çalışmalarda farklı liderlik tarzları (örneğin, otokratik liderlik, mütevazı liderlik) da modele dâhil edilerek farlı boyuttaki liderlik tarzları arasında kıyaslama yapılabilir. 


\section{Kaynakça}

Abas, N. I.; Sawitri, H. S. R.; Puspawati, D. (2018), "Transformational Leadership, Job Performance, and Organizational Citizenship Behavior: Mediating Role of Work Engagement", Sriwijaya International Journal of Dynamic Economics and Business, Vol. 2, No. 4: 363-376.

Aiken, L. S.; West, S. G. (1991), Multiple Regression: Testing and Interpreting Interactions, Newbury Park: CA: Sage.

Ajzen, I. (1991), "The Theory of Planned Behavior", Organizational Behavior and Human Decision Processes, Vol. 50, No. 2: 179-211.

Al Khajeh, E. H. (2018), "Impact of Leadership Styles on Organizational Performance", Journal of Human Reseources Management Research, Vol. 2018, 1-10.

Allen, D. G.; Shore, L. M.; Griffeth, R. W. (2003), "The Role of Perceived Organizational Support and Supportive Human Resource Practices in the Turnover Process", Journal of Management, Vol. 29, No. 1: 99-118.

Alpkan, L.; Bulut, C.; Gunday, G.; Ulusoy, G.; Kilic, K. (2010), "Organizational Support for Intrapreneurship and Its Interaction with Human Capital to Enhance Innovative Performance", Management Decision, Vol. 48, No. 5: 732-755.

Anderson, J. C.; Gerbing, D. W. (1988), "Structural Equation Modeling in Practice: A Review and Recommended Two-Step Approach", Psychological Bulletin, Vol. 103, No. 3: 411-423.

Avolio, B. J.; Yammarino, F. J. (2002), "Introduction to, and Overview of, Transformational and Charismatic Leadership", Transformational and Charismatic Leadership: The Road Ahead, (Ed. B. J. Avolio ve F. J. Yammarino), Oxford: Elsevier Science: 17-23.

Baba, V. V.; Jamal, M. (1991), "Routinization of Job Context and Job Content as Related to Employees ' Quality of Working Life : A Study of Canadian Nurses", Journal of Organizational Behavior, Vol. 12, No. 5: 379-386.

Bass, B. M. (1985), Leadership and Performance Beyond Expectations, New York: Free Press.

Bass, B. M. (1999), "Two Decades of Research and Development in Transformational Leadership", European Journal of Work and Organizational Psychology, Vol. 8, No. 1: 9-32.

Bass, B. M.; Avolio, B. J. (1990), "Developing Transformational Leadership: 1992 and Beyond", Journal of European Industrial Training, Vol. 14, No. 5: 21-27.

Blau, P. M. (1964), Exchange and Power in Social Life, New York: John-Wiley \& Sons Pub.

Bliese, P. D.; Edwards, J. R.; Sonnentag, S. (2017), "Stress and Well-Being at Work: A Century of Empirical Trends Reflecting Theoretical and Societal Influences Paul", Journal of Applied Psychology, Vol. 102, No. 3: 389-402.

Brislin, R. W.; Lonner, W. J.; R.M. Thorndike. (1973), Cross Cultural Research Methods, 1. Basım, New York: John-Wiley \& Sons Pub.

Buil, I.; Martínez, E.; Matute, J. (2019), "Transformational Leadership and Employee Performance: The Role of Identification, Engagement and Proactive Personality", International Journal of Hospitality Management, Vol. 77, 64-75.

Carayon, P.; Smith, M. J.; Haims, M. C. (1999), "Work Organization, Job Stress, and Work-Related Musculoskeletal Disorders", Human Factors, Vol. 41, No. 4: 644-663.

Carless, S. A.; Wearing, A. J.; Mann, L. (2000), "A Short Measure of Transformational Leadership", Journal of Business and Psychology, Vol. 14, No. 3: 389-405.

Chandrasekara, W. (2019), "The Effect of Transformational Leadership Style on Employees Job Satisfaction and Job Performance: A Case of Apparel Manufacturing Industry in Sri Lanka", International Journal of Economics, Commerce and Management, Vol. 7, No. 7: 385-393.

Cheng, B. H.; McCarthy, J. M. (2018), "Understanding the Dark and Bright Sides of Anxiety: A Theory 
of Workplace Anxiety", Journal of Applied Psychology, Vol. 103, No. 5: 537-560.

Choi, Y.; Yoon, D. J.; Kim, D. (2020), "Leader Behavioral Integrity and Employee In-Role Performance: The Roles of Coworker Support and Job Autonomy", International Journal of Environmental Research and Public Health, Vol. 17, 1-14.

Cole, M. S.; Walter, F.; Bruch, H. (2008), "Affective Mechanisms Linking Dysfunctional Behavior to Performance in Work Teams: A Moderated Mediation Study", Journal of Applied Psychology, Vol. 93, No. 5: 945-958.

Conger, J. A.; Kanungo, R. N. (1988), "The Empowerment Process: Integrating Theory and Practice", The Academy of Management Review, Vol. 13, No. 3: 471-482.

De Clercq, D.; Haq, I. U.; Azeem, M. U. (2017), "Perceived Threats of Terrorism and Job performance: The Roles of Job-Related Anxiety and Religiousness", Journal of Business Research, Vol. 78, 23-32.

De Clercq, D.; Haq, I. U.; Azeem, M. U. (2018), "Self-Efficacy to Spur Job Performance: Roles of JobRelated Anxiety and Perceived Workplace Incivility", Management Decision, Vol. 56, No. 4: 891-907.

Deadrick, D. L.; Gardner, D. G. (2008), "Maximal and Typical Measures of Job Performance: An Analysis of Performance Variability Over Time", Human Resource Management Review, Vol. 18, No. 3: 133-145.

Dias, M. A. M. J.; Borges, R. S. G. E. (2017), "Performance and Leadership Style: When Do Leaders and Followers Disagree?", Revista de Administração Mackenzie - RAM, Vol. 18, No. 2: 104-129.

Fila, M. J.; Eatough, E. (2018), "Extending Knowledge of Illegitimate Tasks: Student Satisfaction, Anxiety, and Emotional Exhaustion", Stress and Health, Vol. 34, No. 1: 152-162.

Foa, E. B.; Foa, U. G. (1974), Societal Structures of the Mind, Springfield: Charles C. Thomas.

Fuller, J. B.; Patterson, C. E. P.; Hester, K.; Stringer, D. Y. (1996), "A Quantitative Review of Research on Charismatic Leadership", Psychological Reports, Vol. 78, 271-287.

García-Morales, V. J.; Lloréns-Montes, F. J.; Verdú-Jover, A. J. (2008), "The Effects of Transformational Leadership on Organizational Performance through Knowledge and Innovation", British Journal of Management, Vol. 19, No. 4: 299-319.

Gilbert, M.-H.; Dagenais-Desmarais, V.; St-Hilaire, F. (2017), "Transformational Leadership and Autonomy Support Management Behaviors", Leadership \& Organization Development Journal, Vol. 38, No. 2: 1-38.

Gözükara, I.; Simşek, O. F. (2015), "Linking Transformational Leadership to Work Engagement and the Mediator Effect of Job Autonomy: A Study in a Turkish Private Non-Profit University", Procedia Social and Behavioral Sciences, Vol. 195, 963-971.

Grant, A. M.; Sumanth, J. J. (2009), "Mission Possible? The Performance of Prosocially Motivated Employees Depends on Manager Trustworthiness", Journal of Applied Psychology, Vol. 94, 927-944.

Gross, E. (2017), "Work, Organization, and Stress", Social Stress, (Ed. S. Levine ve N. A. Scotch), London and New York: Routledge.

Hackman, J. R.; Oldham, G. R. (1976), "Motivation Through the Design of Work: Test of a Theory", Organizational Behavior and Human Performance, Vol. 16, 250-279.

Hackman, J. R.; Oldham, G. R. (1980), Work Redesign, Canada: Addison-Wesley Publications.

Harman, H. H. (1976), Modern Factor Analysis, University of Chicago Press.

Hayes, A. F. (2017), Introduction to Mediation, Moderation, and Conditional Process Analysis, Introduction to Mediation, Moderation and Conditional Process Analysis, New York: The Guilford Press.

Hofstede, G. (1980), "Motivation, Leadership and Organization: Do American Theories Apply Abroad?", Organizational Dynamics, Vol. 9, No. 1: 42-63.

Hui, R. T. yin; Sue-Chan, C. (2018), "Variations in Coaching Style and Their Impact on Subordinates' 
Work Outcomes", Journal of Organizational Behavior, Vol. 39, No. 5: 663-679.

Jain, P.; Duggal, T. (2018), "Transformational Leadership, Organizational Commitment, Emotional Intelligence and Job Autonomy: Empirical Analysis on the Moderating and Mediating Variables", Management Research Review, Vol. 41, No. 9: 1033-1046.

Jones, M. K.; Latreille, P. L.; Sloane, P. J. (2016), "Job Anxiety, Work-Related Psychological Illness and Workplace Performance", British Journal of Industrial Relations, Vol. 54, No. 4: 742-767.

Joo, B.-K.; Jeung, C.-W.; Yoon, H. J. (2010), "Investigating the Influences of Core Self-Evaluations, Job Autonomy, and Intrinsic Motivation on In-Role Job Performance", Human Resource Development Quartely, Vol. 21, No. 4: 353-371.

Judge, T. A.; Bono, J. E.; Locke, E. A. (2000), "Personality and Job Satisfaction: The Mediating Role of Job Characteristics", Journal of Applied Psychology, Vol. 85, No. 2: 237-249.

Katou, A. A. (2015), "Transformational Leadership and Organisational Performance", Employee Relations, Vol. 37, No. 3: 329-353.

Katz, D. (1964), "The Motivational Basis of Organizational Behavior", Behavioral Science, Vol. 9, No. 2: 131-146.

Kerr, R.; McHugh, M.; McCrory, M. (2009), "HSE Management Standards and Stress-Related Work Outcomes", Occupational Medicine, Vol. 59, No. 8: 574-579.

Kirkman, B. L.; Rosen, B. (1999), "Beyond Self-Management: Antecedents and Consequences of Team Empowerment", Academy of Management Journal, Vol. 42, No. 1: 58-74.

Krannitz, M. A.; Grandey, A. A.; Liu, S.; Almeida, D. A. (2015), "Workplace Surface Acting and Marital Partner Discontent: Anxiety and Exhaustion Spillover Mechanisms", Journal of Occupational Health Psychology, Vol. 20, No. 3: 314-325.

Lai, F. Y.; Tang, H. C.; Lu, S. C.; Lee, Y. C.; Lin, C. C. (2020), "Transformational Leadership and Job Performance: The Mediating Role of Work Engagement", SAGE Open, Vol. 10, No. 1: 1-11.

Lim, S.; Tai, K. (2014), "Family incivility and Job Performance: A Moderated Mediation Model of Psychological Distress and Core Self-Evaluation", Journal of Applied Psychology, Vol. 99, No. 2: 351-359.

Lussier, R. N.; Achua, C. F. (2007), Effective Leadership, Thomson South-Western: OH.

Mackenzie, S. B.; Podsakoff, P. M.; Rich, G. A. (2001), "Transformational and Transactional Leadership and Salesperson Performance The Dangers of Poor Construct Conceptualization View project", Journal of the Academy of Marketing Science, Vol. 29, No. 2: 115-134.

Manzoor, F.; Wei, L.; Nurunnabi, M.; Subhan, Q. A.; Shah, S. I. A.; Fallatah, S. (2019), "The Impact of Transformational Leadership on Job Performance and CSR as Mediator in SMEs", Sustainability, Vol. 11, 1-14.

Mao, J.; Chang, S.; Gong, Y.; Xie, J. L. (2021), "Team Job-Related Anxiety and Creativity: Investigating Team-Level and Cross-Level Moderated Curvilinear Relationships", Journal of Organizational Behavior, Vol. 42, 34-47.

Martin, R.; Guillaume, Y.; Thomas, G.; Lee, A.; Epitropaki, O. (2016), "Leader-Member Exchange (LMX) and Performance: A Meta-Analytic Review", Personnel Psychology, Vol. 69, No. 1: 67-121.

Masa'deh, R.; Obeidat, B. Y.; Tarhini, A. (2016), "A Jordanian Empirical Study of The Associations Among Transformational Leadership, Transactional Leadership, Knowledge Sharing, Job Performance, and Firm Performance: A Structural Equation Modelling Approach", Journal of Management Development, Vol. 35, No. 5: 681-705.

McCarthy, J. M.; Trougakos, J. P.; Cheng, B. H. (2016), "Are Anxious Workers Less Productive Workers? It Depends on the Quality of Social Exchange", Journal of Applied Psychology, Vol. 101, No. 2: 279-291.

Morgan, J. I.; Harris, P. R. (2015), "Evidence That Brief Self-Affirming Implementation Intentions Can 
Reduce Work-Related Anxiety in Downsize Survivors", Anxiety, Stress and Coping, Vol. 28, No. 5: 563575.

Morgeson, F. P.; Delaney-Klinger, K.; Hemingway, M. A. (2005), "The Importance of Job Autonomy, Cognitive Ability, and Job-Related Skill for Predicting Role Breadth and Job Performance", Journal of Applied Psychology, Vol. 90, No. 2: 399-406.

Mortensen, R. (2014), "Anxiety, Work, and Coping", The Psychologist-Manager Journal, Vol. 17, No. 3: 178-181.

Muller, D.; Judd, C. M.; Yzerbyt, V. Y. (2005), "When Moderation is Mediated and Mediation is Moderated", Journal of Personality and Social Psychology, Vol. 89, No. 6: 852-863.

Nauman, S.; Malik, S. Z.; Jalil, F. (2019), "How Workplace Bullying Jeopardizes Employees' Life Satisfaction: The Roles of Job Anxiety and Insomnia", Frontiers in Psychology, Vol. 10, 1-13.

Parker, D. F.; DeCotiis, T. A. (1983), "Organizational Determinants of Job Stress", Organizational Behavior and Human Performance, Vol. 32, 160-177.

Pattnaik, S. C.; Sahoo, R. (2021), "Transformational Leadership and Organizational Citizenship Behaviour: The Role of Job Autonomy and Supportive Management", Management Research Review, 118.

Podsakoff, P. M.; MacKenzie, S. B.; Lee, J. Y.; Podsakoff, N. P. (2003), "Common Method Biases in Behavioral Research: A Critical Review of the Literature and Recommended Remedies", Journal of Applied Psychology, Vol. 88, No. 5: 879-903.

Pollitt, C. (2018), "Performance Management 40 Years on: A Review. Some Key Decisions and Consequences", Public Money and Management, Vol. 38, No. 3: 167-174.

Preacher, K. J.; Hayes, A. F. (2008), "Asymptotic and Resampling Strategies for Assessing and Comparing Indirect Effects in Multiple Mediator Models", Behavior Research Methods, Vol. 40, No. 3: 879-891.

Preacher, K. J.; Rucker, D. D.; Hayes, A. F. (2007), "Addressing Moderated Mediation Hypotheses: Theory, Methods, and Prescriptions", Multivariate Behavioral Research, Vol. 42, No. 1: 185-227.

Rhoades, L.; Eisenberger, R. (2002), "Perceived Organizational Support: A Review of the Literature", Journal of Applied Psychology, Vol. 87, No. 4: 698-714.

Scott, S. G.; Bruce, R. A. (1994), "Determinants of Innovative Behavior : A Path Model of Individual Innovation in the Workplace", The Academy of Management Journal, Vol. 37, No. 3: 580-607.

Shafie, B.; Baghersalimi, S.; Barghi, V. (2013), "The Relationship Between Leadership Style and Employee Performance: Case Study of Real Estate Registration Organization of Tehran Province", Singaporean Journal of Business, Economics and Management Studies, Vol. 2, No. 5: 21-29.

Shalley, C. E.; Gilson, L. L. (2004), "What Leaders Need to Know: A Review of Social and Contextual Factors That Can Foster or Hinder Creativity", Leadership Quarterly, Vol. 15, 33-53.

Shamir, B.; House, R. J.; Arthur, M. B. (1993), "The Motivational Effects of Charismatic Leadership : A Self-Concept Based Theory", Organization Science, Vol. 4, No. 4: 577-594.

Sigler, T. H.; Pearson, C. M. (2000), "Creating an Empowering Culture: Examining the Relationship Between Organizational Culture and Perceptions of Empowerment", Journal of Quality Management, Vol. 5, 27-52.

Spector, P. E.; Dwyer, D. J.; Steve, M. J. (1988), "Relation of Job Stressors to Affective, Health and Performance Outcomes: A Comparison of Multiple Data sources", Journal of Applied Psychology, Vol. 73, No. 1: 11-19.

Svendsen, M.; Unterrainer, C.; Jonsson, T. F. (2018), "The Effect of Transformational Leadership and Job Autonomy on Promotive and Prohibitive Voice: A Two-Wave Study", Journal of Leadership \& Organizational Studies, Vol. 25, No. 2: 171-183. 
Taylor, S.; Koch, W. J.; Crockett, D. J. (1991), "Anxiety Sensitivity, Trait Anxiety, and the Anxiety Disorders", Journal of Anxiety Disorders, Vol. 5, No. 4: 293-311.

Vigoda-Gadot, E. (2007), "Leadership Style, Organizational Politics, and Employees' Performance: An Empirical Examination of Two Competing Models", Personnel Review, Vol. 36, No. 5: 661-683.

Yukl, G. (1999), "An Evaluation of Conceptual Weaknesses in Transformational and Charismatic Leadership Theories", Leadership Quarterly, Vol. 10, No. 2: 285-305.

Zhu, Y.; Akhtar, S. (2014), "How Transformational Leadership Influences Follower Helping Behavior: The Role of Trust and Prosocial Motivation", Journal of Organizational Behavior, Vol. 35, No. 3: 373-392. 


\section{Extended Summary}

\section{Turkish Adaptation of the Job-Related Anxiety Scale and the Relationship between Transformational Leadership on Job Performance: The Mediating Role of Job Autonomy and Moderating Role of Job-Related Anxiety}

Meeting rapidly changing customer expectations and reducing the negative effects of increasing environmental uncertainties in the last four decades have been important determinants of organizational performance. The relationships between leaders and members of an organization are of great importance in reducing rapidly changing and increasingly complex environmental uncertainties and achieving the goals of an organization. Today, leaders need to ensure that employees perform beyond their official definitions of duty to meet the goals of an organization. For this reason, leadership style may be an important factor affecting the performance of an organization and its employees. Research has shown that some leadership styles (e.g., transactional leadership) negatively affect and reduce the performance of an employee, while some leadership styles (e.g., transformational leadership, humble leadership) positively affect and increase the performance of an employee. Although studies show that the transformational leader has a significant effect on performance, there are limited studies on the conditions under which this effect differs.

The purpose of this study is to adapt the job-related anxiety scale developed by Parker and DeCotiis (1983) into Turkish. Besides, the mediating role of job autonomy and the moderator role of job-related anxiety in the effect of transformational leadership on job performance were examined. A quantitative research method was used in the study and data from two different samples were obtained by questionnaire technique. To adapt the scale, the first sample $(n=159)$ consisting of nurses and, in testing the research hypotheses the second sample $(n=237)$ consisting of employees of a private company operating in the service sector in Turkey was used. Data were analyzed using SPSS 25, AMOS 24, and Process Macro statistical programs.

A seven-item and one-dimensional "Global Transformational Leadership Scale" that developed by Carless et al., (2000) was used to measure transformative leadership; a three-item and one-dimensional "Job Autonomy" scale that developed by Hackman and Oldham (1980) was used to determine employees ' levels of job autonomy in the organization; a five-item and one-dimensional "JobRelated Anxiety Scale" that developed by Parker ve DeCotiis (1983) was used to measure job- related anxiety levels of employees; a four-item and one-dimensional "Job Performance" scale that developed by Kirkman and Rosen (1999), Sigler and Pearson (2000) was used to measure the job performance of employees.

In this study, data from a sample of nurses (the first sample) was used to determine the validity and reliability of the job-related anxiety scale. The necessary analyses were made to determine both the structural validity and reliability of the job-related anxiety scale, and the results showed that the validity and reliability of the 5-item job-related anxiety scale were ensured. Therefore, the results suggested that the job-related anxiety scale is suitable for studies conducted in Turkey, so it can be used to determine the direction of work-related concerns of employees.

Moreover, three hypotheses were tested in this study. First, the mediation of job autonomy in the relationship between transformational leadership and job performance was tested using the simple mediating model (hypothesis 1). The results have shown that job autonomy mediates the association between transformational leadership and job performance. Hypothesis 1 is supported by another statement. Second, the regulatory role of job-related anxiety in the relationship between job autonomy and job performance was examined (hypothesis 2). The results showed that there was a regulatory effect of job-related anxiety in the relationship between job autonomy and job performance. In other words, the positive effect of job autonomy on job performance is weak when job-related anxiety is high and strong when it is low. The results supported the second hypothesis. Finally, the regulatory role of job-related anxiety in the indirect effect of transformational leadership on job performance through job autonomy was examined (hypothesis 3). The findings showed that the indirect effect of transformational leadership on job performance (thro ugh job autonomy) is weak when job-related anxiety is high and strong when it is low, which supports the third hypothesis.

In the current study, several important contributions have been made by examining the effect of transformational leadership on job performance as an instrument of job autonomy and the regulatory role of job-related anxiety. First of all, Turkish adaptation of the job-related anxiety scale, which was developed by Parker and DeCotiis (1983), was carried out by testing the reliability and validity examinations, showing that the Turkish adaptation of the scale in question is statistically usable. Second of all, in light of the previous research, which suggests the investigations confounders in the relationship between transformational leadership and job performance (e.g., García-Morales vd., 2008; Lai vd., 2020; Manzoor vd., 2019), in the current research the role of job autonomy as an intermediary in this relationship was examined and contributed to previous research findings. Lastly, the current research has identified conditions for how transformational leaders can effectively improve employees' job performance. In light of this, the current research contributed to previous research findings by showing that the indirect impact of transformational leadership on job performance through job autonomy differs depending on the level of employee's job-related anxiety.

In addition to the theoretical and practical contributions mentioned above, in the current study, there are some limitations. The first limitation is that the relationships between variables cannot be fully determined due to the cross-sectional structure of the research. Future studies should adopt a longitudinal research design. The second limitation is that although the absence of common method bias in the data has been proven by Harman's (1976) single-factor test, some researchers (e.g., Podsakoff et al., 2003) stated that this method is weak to prove that there is no common method bias. So that, in the current research, there may be a common method bias due to using a single measurement method. Future research may apply a multi-method approach to prevent bias. The last limitation of the current research is that only the effects of transformational leadership style have been studied and different leadership styles have not been taken into account. In future studies, different leadership styles (for example, autocratic leadership) can also be included in the model, comparing different leadership styles of decency. 